to the same variety and were introduced at the level of 70 per cent into isonitrogenous diets ( $20 \% \mathrm{CP}$ ) offered till the age of 9 weeks. In these conditions, a marked effect was noticed in favour of waxy maize:

Daily mean gain: $470 \mathrm{~g}$ (group 2) versus $\mathbf{4 3 4} \mathrm{g}$ (group 1), i.e. a significant increase of 8 per cent $\left(\mathrm{P}<0.05\right.$ ); feed conversion ratio 1.76 (group 2) versus $\mathrm{I} .8_{4}$ (group $\left.\mathrm{I}\right)(\mathrm{P}<\mathrm{0.10}$ ).

Parallel to that an in vitro digestibility assay was made with the two types of maize of trial $C$. The results showed that the breakdown of waxy maize starch was more rapid in the presence of piglet pancreatic juice, a fact suggesting that the energy of this type of maize is more available.

\title{
Influence of diet on respiratory quotients and fat deposition in growing pigs
}

\author{
Geneviève CHARIET-LÉRY et Marie-Thérèse MOREL \\ Laboratoive de Physiologie de la Nutrition, \\ I.N.R.A.C.N.R.Z., 78350 Jouy-en-Josas (France)
}

\begin{abstract}
Short-lasting measurements of gascous exchanges in total confinement repeaterl several times during the day were used to study variations in these exchanges and in the respiratory quotient (RQ) during $23 \mathrm{~h}$ after meal eating in growing pigs $(3.5-65 \mathrm{~kg})$.

$R Q$ variations showed that lipogenesis took place during the first post eating hours, whatever the protein concentration of the diet, protein free normal or high protein level $(25 \%$ DM). In the latter conditions values inferior to $1(0,85)$ were observed when lipogenesis was occurring.

Fat deposition W.75 was highly correlated with ingested carbohydrates $/ W .75(r=-0.99$ $\mathrm{l}^{\prime}<\mathrm{o.oI}$ ), and energy efficiency of fat deposition (kf) was 0.76 . Any lowering of the carbohydrate supply compensated for by an increase in the protein supply slowed down the lipogenesis in growing pigs.
\end{abstract}

\section{Ad libitum or restricted feeding of female pigs receiving a maize soya-bean diet in the form of meal or pellet during the growing-finishing period}

\author{
J. CASTAING (1) et M. LEUILLET $\left({ }^{2}\right)$ \\ (1) Association générale des Producteurs de Maïs, \\ I, place de Lestapis, 6 fooo Pau (France) \\ (2) Institut Technique des Céréales et des Fourrages, \\ 8, avenue du Président-Wilson, 75116 Paris
}

Four feeding schedules were studied in female pigs derived from Large White $\times$ Jandrace dams and Latidrace sires. The diets were based on maize and offered either in the form of meal or pellets:

- feed resfiction during the whole growing period. The feed restriction plan was that usually applied in our previous trials. It was established according to the weight of the animals and involved a maximum supply of $80 \mathrm{~kg}$ feed $(2,8 \mathrm{~kg} / \mathrm{day} / \mathrm{animal})$. animal, :

_ad-libitum feeding until $60 \mathrm{~kg}$ live weight followed by a feeding plateau of $2,5.5 \mathrm{~kg} / \mathrm{day} /$

$\therefore$ ad libitum feeding until $60 \mathrm{~kg}$ live weight then a feeding plateau of $2.8 \mathrm{~kg} / \mathrm{day} / \mathrm{animal}$,

- ad libitum feeding until slaugiter.

Considering the overall experimental period, the daily mean intakes regularly increased from the most restricted treatment i to the ad libitum treatment 4 . The values obtained were 
the following: $2.23 ; 2.25 ; 2.39$ and $2.46 \mathrm{~kg} / \mathrm{day}$, the first two treatments differing significantly from the two others.

The growth rates obtained were related to the feed intake. Accordingly, the feed conversion ratios were similar for the 4 treatments (from 2.97 to 3.04 ), the highest value being obtained with ad libitum feeding.

It was observed that in most cases, the daily feed intakes were lower with pellets. This difference was statistically significant according to the results of the 4 treatments.

Growth performances and feed conversion ratios were always improved with pellets and this was all the more marked as the restriction was severe.

No significant difference was noticed between groups with respect to cutting criteria. The loin /backfat ratio was in favour of carcasses from animals having been restricted after ad libitum feeding and evolved parallel to the intensity of feed restriction. This was also the case for average backfat thickness. For these two criteria, the results obtained with progressive feed restriction (treatment $\mathrm{r}$ ) were located between those obtained with the more liberal treatments.

Consequently, fattening length of pigs, total feed intake and conmercial grading of carcasses cannot be optimized simultaneously.

\title{
Utilization of different varieties of fodder wheat by growing finishing pigs
}

\author{
J. P. BOUARD et M. LEUILIET \\ Institut Technique des Cévéales et des Fourrages, \\ 8, avenue du Président-Wilson, 75116 Paris
}

Two experiments were carried out with the aim of defining more accurately the feeding value of diets based on new varieties of wheat unfitted for bread-making as compared with various varieties fitted for bread-making. In the first experiment the animals were fed ad libitum during the growing-finishing period and in the second one, they were restricted during the finishing period.

The results obtained with the variety " Maris-Huntsman" in the two experiments were similar to those recorded with the classical varieties. Accordingly, data available about wheat can also be applied to the former variety.

The variety " Clement" exhibited the same feed efficiency in females and castrated males as the other varieties. However, a slight lowering in the intake level was noticed in castrated males leading to growth rate reduction.

Further assays should be performed to confirm the feeding value of the variety "Clement".

\section{Reduction of the protein level in wheat based diets offered to growing-finishing pigs}

\author{
J. CASTAING (1) et M. LeULlLet ${ }^{(2)}$ \\ (1) Association générale des Producteut's de Maïs \\ $I$, place de Lestapis, 64000 Pau (Fvance) \\ $\left({ }^{2}\right)$ Institut Technique des Céréales et des Fourrages \\ 8, avenue du Président-Wilson. 75It6 Paris
}

\begin{abstract}
Six wheat based diets differing by the protein supply (quantitative or qualitative) and protein source (soya-bean meal alone or combined with lucerne meal) were compared in this study using growing-finishing pigs.

The best growth performances were obtained with the highest crude protein level (i $8 \%)$ and then regularly decreased with the levels of 16.5 and 15 per cent. The differences were
\end{abstract}

